\title{
AN OUTLINE OF THE MAIN MINERAL RESOURCES OF GHANA*
}

\author{
Joseph A. Gaze**
}

\section{INTRODUGTION}

With an area of 239,460 sq km, and a rather complex physiographical and geological features, the Republic of Ghana, formerly known as the Gold Coast, is endowed with a vast range of minerai resources. Consequently, mining and mineral extraction had been quite indigenous to the country, and the winning of precious minerals such as gold and diamonds, through indigenous methods, dates as far back as the 6th century and probably beyond.

However, the first mine was opened by the Portuguese as late as 1482, and a well organized Geological Survey Department was not formed until 1913. Since then the mining and mineral processing industry in Ghana has gone through many phases. Presently, the only minerals being exploited are gold, manganese, bauxite, diamond, kaolin and limestone, and minerals account for only about $25 \%$ of the country's total export values. However, the existence of large reserves of proven ore deposits of various other economic minerals such as iron ore, clay and dolomite, appreciable quantities of probable ore deposits of such minerals as barite, potash feldspar, and andalusite, and potential ore deposits of silicates, road building materials, common salt and petroleum cannot be over-emphasized.

\section{MAIN MINERAL DEPOSITS}

The main mineral deposits of Ghana can be categorized into Metallic and Non-metallic Minerals. Below is a detailed discussion of the minerals and their deposits according to the above categories and in alphabetical order.

\section{METALIIG MINERALS}

\section{ALUMINIUM}

Ghana does not as a nation produce aluminium from her bauxite resources. The bauxite produced in the country at Awaso is exported after the silica has been washed out of the raw ore, to Burntisland, Scotland, for refining to alumina and finally into aluminium related products such as toothpaste manufacture and aluminium salts, particularly sulphates for use as flocculant in water treatment.

However, the Volta Aluminium Company Limited (VALCO) owned by Kaiser Aluminium and Chemical Corporation (90\%) and Reynolds Metals Company (10\%), both of the U.S.A., has a 200,000 tonnes per year aluminium smelter at Tema where alumina, imported from Jamaica, is smelted and processed into primary and alloyed aluminium ingots and exported. This aluminium plant at Tema is the largest producer of primary aluminium in Africa and one of the largest private enterprises in Ghana. Table 1 shows Valco's aluminium production for the past 15 years i.e. 19691983.

* 平成元年 6 月14日本会第82回例会において発表

** Industrial Research Inst., Accra, Ghana (現京都大学研究留学生) (Western Cashngs Limited, Ghana.) 平成元年 4 月12日受理 
Table 1. Valco's yearly aluminium production from 1969-1983. (Source: Mining Annual Review and Valco's Annual Reports).

\begin{tabular}{lc}
\hline Year & Production of Aluminium (in tonnes) \\
\hline 1969 & 111200 \\
1970 & 113000 \\
1971 & 111100 \\
1972 & 133000 \\
1973 & 152000 \\
1974 & 157000 \\
1975 & 143000 \\
1976 & 151000 \\
1977 & 153468 \\
1978 & 113462 \\
1979 & 168729 \\
1980 & 191195 \\
1981 & 190497 \\
1982 & 174246 \\
1983 & 42453 \\
\hline
\end{tabular}

The low production in 1978 was due to a general power failure in Ghana in May, 1978 causing the closure of about $60 \%$ plant capacity at Valco. In 1983, although Valco began the year with three of its five potlines in operation, by year-end, the plant was entirely shut down due to the disastrously low inflow of water into the Volta Lake thus creating an energy crisis in Ghana and hence the low aluminium production for the year 1983.

\section{BAUXITE}

Ghana is one of the West African countries which is rich in bauxite deposits. The bauxite deposits could be classified as lateritic-silicate types, with the main minerals being gibbsite, and small amounts of boehmite kaolinite and iron minerals.

The main occurrences of bauxite in Ghana are at Sefwi-Bekwai in the Western Region, AyaNyinahin in the Ashanti Region, Atewa Range near Kibi and at Mt. Ejuanema both in the Eastern Region. Their locations are shown in Fig. 1.

The approximate reserves of the deposits are as follows:

$\begin{array}{lc}\text { Sefwi-Bekwai } & 19,000,000 \text { tonnes } \\ \text { Aya-Nyinahin group } & 350,000,000 \text { tonnes } \\ \text { Kibi } & 150,000,000 \text { to } 180,000,000 \text { tonnes } \\ \text { Mt. Ejuanema } & 5,100,000 \text { tonnes }\end{array}$

Even though the chemical composition of the various deposits vary considerably, they are generally similar to the following chemical analysis obtained from Mt. Supirri, the largest hill in the Affo group of hills of the Sefwi-Bekwai deposits. (Table 2.)

At present, only the deposits at Sefwi-Bekwai (popularly known as the Awaso deposits) are being exploited, however, of the four deposits, only the Kibi and Aya-Nyinahin deposits are of such sizes as to warrant long term industrial investment. The production figures over the last 30 years of Ghana Bauxite Company, the only company exploiting and exporting bauxite in Ghana at the moment is shown in Table 3.

\section{GOLD}

The name Ghana, formerly the Gold Coast, has been associated with gold from time immemorial, 


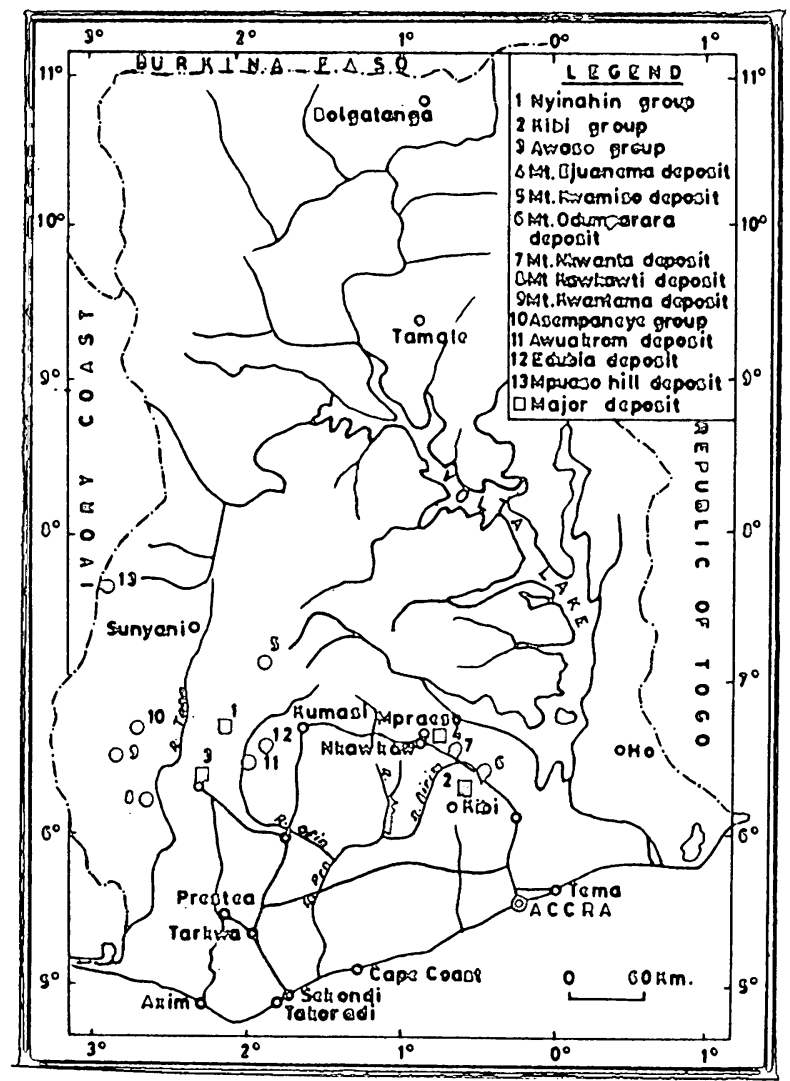

1. Nyinahin group;

4. Mt. Ejuanema group;

7. Mt. Nkwanta deposit;

10. Asempaneye group;

13. Mpuasu Hill deposit.
2. Kibi group;

5. Mt. Kwamisa deposit;

8. Mt. Kawkawti deposit;

11. Awuakrom deposit;
3. Awaso group;

6. Mt. Odumparara deposit;

9. Mt. Kwantama deposit;

12. Edubia deposit;

Fig. 1 The bauxite deposits of Ghana. (The four main deposits are in italics)

for gold was found in such common use among the people of Ghana by the European sailors and merchant adventurers of the 15th and 16th centuries that, they described the country as the Gold Coast.

Table 2. The result of the chemical analysis of bauxite from Mt. Supirri, Sefwi-Bekwai.

\begin{tabular}{|c|c|c|c|c|c|c|c|c|}
\hline \multicolumn{9}{|c|}{ Sample numbers } \\
\hline & 7677 & 7684 & $7705-14$ & $9250-$ & $9256-60$ & $9261-3$ & 9909-19 & $9278-93$ \\
\hline $\mathrm{SiO}_{2} \ldots \ldots \ldots$ & 1,94 & 0,37 & 0,82 & 0,44 & 0,64 & 0,62 & 2,40 & 0,45 \\
\hline $\mathrm{Al}_{2} \mathrm{O}_{3} \quad \ldots \ldots$ & 18,86 & 59,69 & 57,51 & 57,47 & 60,68 & 61,08 & 52,61 & 52,07 \\
\hline $\mathrm{Fe}_{2} \mathrm{O}_{3} \ldots \ldots \ldots$ & 61,12 & 6,01 & 8,70 & 9,75 & 4,20 & 4,10 & 14,14 & 16,40 \\
\hline $\mathrm{TiO}_{2} \ldots \ldots \ldots$ & 0,24 & 0,75 & 1,50 & 1,00 & 1,11 & 0,87 & 1,31 & 1,58 \\
\hline $\mathrm{H}_{2} \mathrm{O}_{+} \ldots \ldots \ldots$ & 17,71 & 33,22 & 31,08 & 30,18 & 32,17 & 32,32 & 28,23 & 27,80 \\
\hline $\mathrm{H}_{2} \mathrm{O}-\ldots \ldots \ldots$ & - & - & - & 1,02 & 0,76 & 1,05 & 1,22 & 0,92 \\
\hline $\mathrm{CaO} \ldots . . . .$. & - & - & - & 0,18 & 0,33 & 0,25 & 0,30 & 0,16 \\
\hline $\mathrm{MgO} . . . . . . .$. & - & - & - & - & - & - & - & 0,03 \\
\hline $\mathrm{V}_{2} \mathrm{O}_{3} \ldots \ldots \ldots$ & - & - & - & 0,04 & 0,03 & 0,02 & 0,05 & 0,04 \\
\hline
\end{tabular}


Table 3. Bauxite production over the last 30 years by Ghana Bauxite Company (Source: Annual reports of Ghana Chamber of Mines and Ghana Bauxite Co. Limited).

\begin{tabular}{|c|c|c|c|}
\hline \multicolumn{4}{|c|}{ Ore (in tonnes) } \\
\hline Year & Produced & Railed & Shipped \\
\hline $1954-55$ & 167966 & 179155 & 178756 \\
\hline $1955-56$ & 139166 & 100407 & 83691 \\
\hline $1956-57$ & 182598 & 165810 & 154358 \\
\hline $1957-58$ & 180480 & 198418 & 207901 \\
\hline $1958-59$ & 186879 & 210653 & 169321 \\
\hline $1959-60$ & 197938 & 170814 & 161619 \\
\hline $1960-61$ & 213767 & 232613 & 232659 \\
\hline $1961-62$ & 207929 & 225219 & 216887 \\
\hline $1962-63$ & 225955 & 281038 & 272075 \\
\hline $1963-64$ & 271025 & 257455 & 221231 \\
\hline 1964-65 & 278589 & 280096 & 277066 \\
\hline 1965-66 & 312508 & 270786 & $274 \quad 441$ \\
\hline $1966-67$ & 333458 & 347651 & 314391 \\
\hline $1967-68$ & 317171 & 305365 & 335844 \\
\hline 1968-69 & 247999 & 244826 & 240502 \\
\hline 1969-70 & 259993 & 314624 & 290164 \\
\hline $1970-71$ & 361038 & 328594 & 347522 \\
\hline $1971-72$ & 356479 & 359104 & 313623 \\
\hline $1972-73$ & 330351 & 328225 & 319475 \\
\hline 1973-74 & 327627 & 338793 & 355283 \\
\hline 1974-75 & 383087 & 374463 & 398499 \\
\hline $1975-76$ & 282084 & 259158 & 322327 \\
\hline 1976-77 & 271090 & 276088 & 249849 \\
\hline $1977-78$ & 271448 & 280592 & 251588 \\
\hline 1978 & 329856 & 301403 & 340575 \\
\hline 1979 & 213679 & 236660 & 250585 \\
\hline 1980 & 224501 & 187423 & 196892 \\
\hline 1981 & 179598 & 173159 & 156769 \\
\hline 1982 & 63530 & 103422 & 92954 \\
\hline 1983 & 70235 & 57186 & 82310 \\
\hline
\end{tabular}

There is a wide spread occurrence of gold in Ghana. The three main types of auriferous deposits are;

1. the reef, vein or lode-type gold deposits

2. auriferous quartz-pebble conglomerates

3. recent alluvial and eluvial deposits

The auriferous quartz veins or reefs associated with sulphide minerals are so far the deposits yielding the country's largest amounts of gold. Values in the reefs are high but patchy and may range from nil to an average of $34 \mathrm{gm} /$ tonne. Values between $170 \mathrm{gm} /$ tonne and $850 \mathrm{gm} /$ tonne are not uncommon in rich areas such as Obuasi and Konogo, but such lodes are of limited extent.

At present, there are five producing gold mines in Ghana. These are, the Ashanti Goldfields Corporation (Ghana) Limited at Obuasi, the State Gold Mining Corporation mines which comprises, Tarkwa Goldfields Limited, Prestea Goldfields Limited, both in the Western Region, Konogo Goldfields Limited in the Ashanti Region, and Dunkwa Goldfields Limited in the Central Region. 


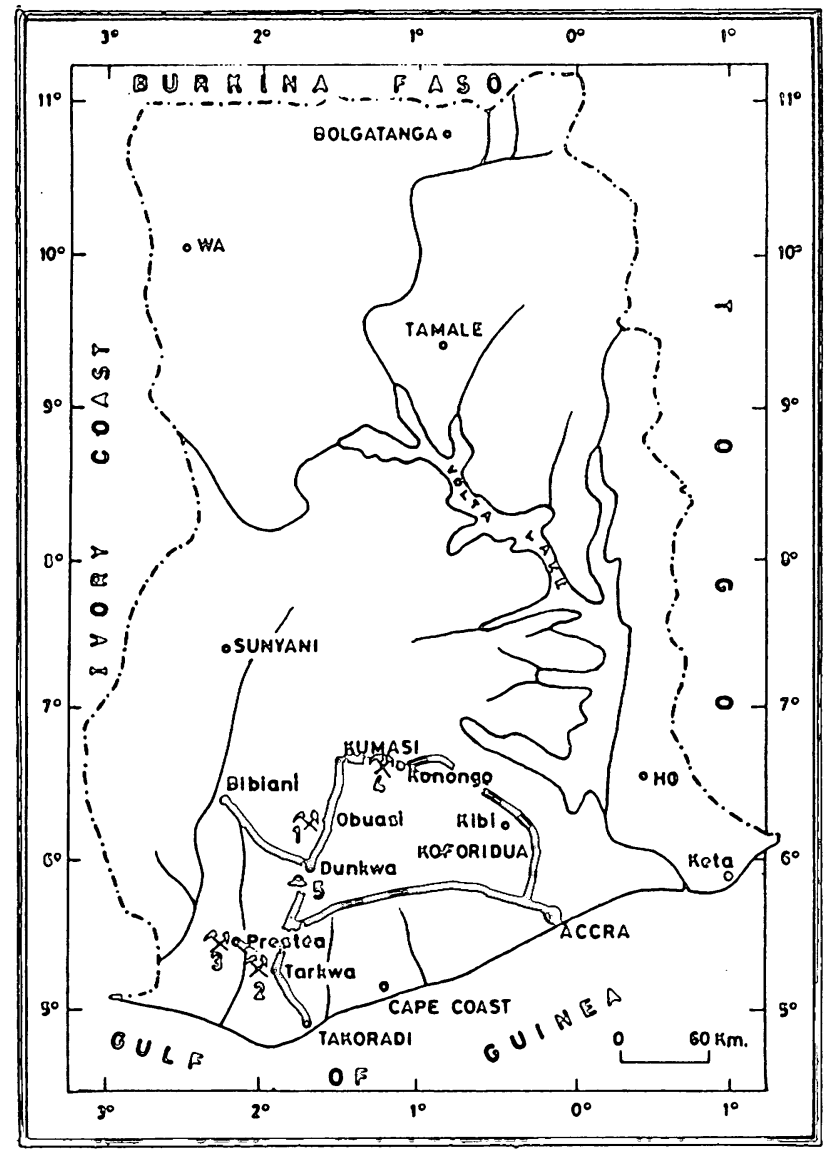

\section{LEGEND}

20. Deep mining. \& Surface mining. (Dredging)

Fig. 2 Locations of the 5 gold mines in Ghana

The locations of these mines are shown in Fig. 2.

Ashanti Goldfields Corporation (Ghana) Limited, the biggest mine, has a mineral concession area of $259 \mathrm{sq} \mathrm{km}$ and mostly treating sulphide ores averaging $10.5 \mathrm{dwt} / \mathrm{ton}$, have from 1897 to 1983 produced 17,265,762 fine ounces of gold. Their ore reserves position as at 1981/82 stcod at 5,557,097 tonnes with an average grade of $12.5 \mathrm{dwt} /$ ton.

Tarkwa Goldfield Limited property covers an area of approximately $280 \mathrm{sq} \mathrm{km}$. The gold of this mine usually occur in the conglomerates of the banket series, which are composed of quartzpebbles and are nearly always barren. From 1969 to 1983 it has produced a total of 684,702 fine ounces of gold, and its proven ore reserve position as at 1980/81 was 1,743,035 tonnes with an average grade of $5.6 \mathrm{dwt} / \mathrm{ton}$.

Prestea Goldfields Limited, treating both sulphide ores and quartz conglomerates, for a period of 14 years (1969-1983) produced a total of 1,159,147 fine ounces of gold. Its proven ore reserve position as at $1980 / 81$ stood at 1,914,654 tonnes, averaging $4.91 \mathrm{dwt} / \mathrm{ton}$.

Konogo Goldfields Limited has a mineral concession area of about $52 \mathrm{sq} \mathrm{km}$ and its production in 14 years (1969-1983) amounted to 76,486 fine ounces of gold. Its ore reserves at 1977/78 was 
Table. 4 Ghana's percentage annual production of gold as compared to the total estimated world production since 1960 .

\begin{tabular}{cccc}
\hline Year & $\begin{array}{c}\text { World production } \\
\text { (in fine ounces) }\end{array}$ & $\begin{array}{c}\text { Ghana's production } \\
\text { (in fine ounces) }\end{array}$ & $\begin{array}{c}\text { Percentage of } \\
\text { world production }\end{array}$ \\
\hline 1960 & 37809000 & 915317 & 2,42 \\
1961 & 39294000 & 878459 & 2,24 \\
1962 & 41600000 & 823115 & 1,98 \\
1963 & 43147000 & 911663 & 2,11 \\
1964 & 44841000 & 912592 & 2,04 \\
1965 & 46225000 & 851090 & 1,84 \\
1966 & 46580000 & 708906 & 1,52 \\
1967 & 45737000 & 724134 & 1,58 \\
1988 & 46165000 & 575346 & 1,25 \\
1969 & 46612000 & 750435 & 1,61 \\
1970 & 47522000 & 714442 & 1,50 \\
1971 & 46495000 & 693770 & 1,49 \\
1972 & 44843000 & 710013 & 1,58 \\
1973 & 42997000 & 731711 & 1,70 \\
1974 & 40124000 & 709550 & 1,77 \\
1975 & 38675000 & 583103 & 1,51 \\
1976 & 39883000 & 515654 & 1,29 \\
1977 & 30538900 & 531084 & 1,74 \\
1978 & 30806000 & 465651 & 1,51 \\
1979 & 30243500 & 387730 & 1,28 \\
1980 & & 349870 & - \\
\hline & & & \\
\end{tabular}

72,810 tonnes with an average grade of $6.39 \mathrm{dwt} / \mathrm{ton}$.

Dunkwa Goldfields Limited, the only gold concession in Ghana where gold is recovered from river gravels by the dredge mining method, has a concession area covering $1.6 \mathrm{~km}$ on either side of the Ofin River, and about $60 \mathrm{~km}$ upstream. Its total gold production from 1971 to 1983 was 116,186 fine ounces of gold, and as at 1980/81., its ore reserves position was 386,956,169 cubic yards.

Table 4 shows Ghana's percentage annual production of gold as compared to the total estimated world production since 1960 .

Aside these five operating mines and their concessions, there are many more auriferous horizons in Ghana and there are several mines which have been closed down or abandoned due to reasons which are no longer valid. When categorized under the three fold classifications of mine, prospect, and showings, there could easily be identified in Ghana about 20 mines, about 50 prospects (lode, banket and alluvial), and over 400 showings.

IRON

There are three main iron ore deposits of potential industral or commercial importance in Ghana. These are 1. the Shieni sedimentary iron ore, 2. the Opon-Mansi lateritic ore and 3. the Pudo titaniferousmagnetiferous iron ore. Fig. 3 shows the locations of both the major and minor iron ore deposits of Ghana.

The Shieni deposits entirely located in the Northern Region of the country and is composed mainly of hematites and hydrohematite, has an estimated reserve of 270 million tonnes of iron ore with more than $45 \%$ iron and less than $30 \%$ silica. At the southern portion of the deposit, where the quality of ore is lower, a rough estimate puts the reserves at about 400 million tonnes. In addition, 


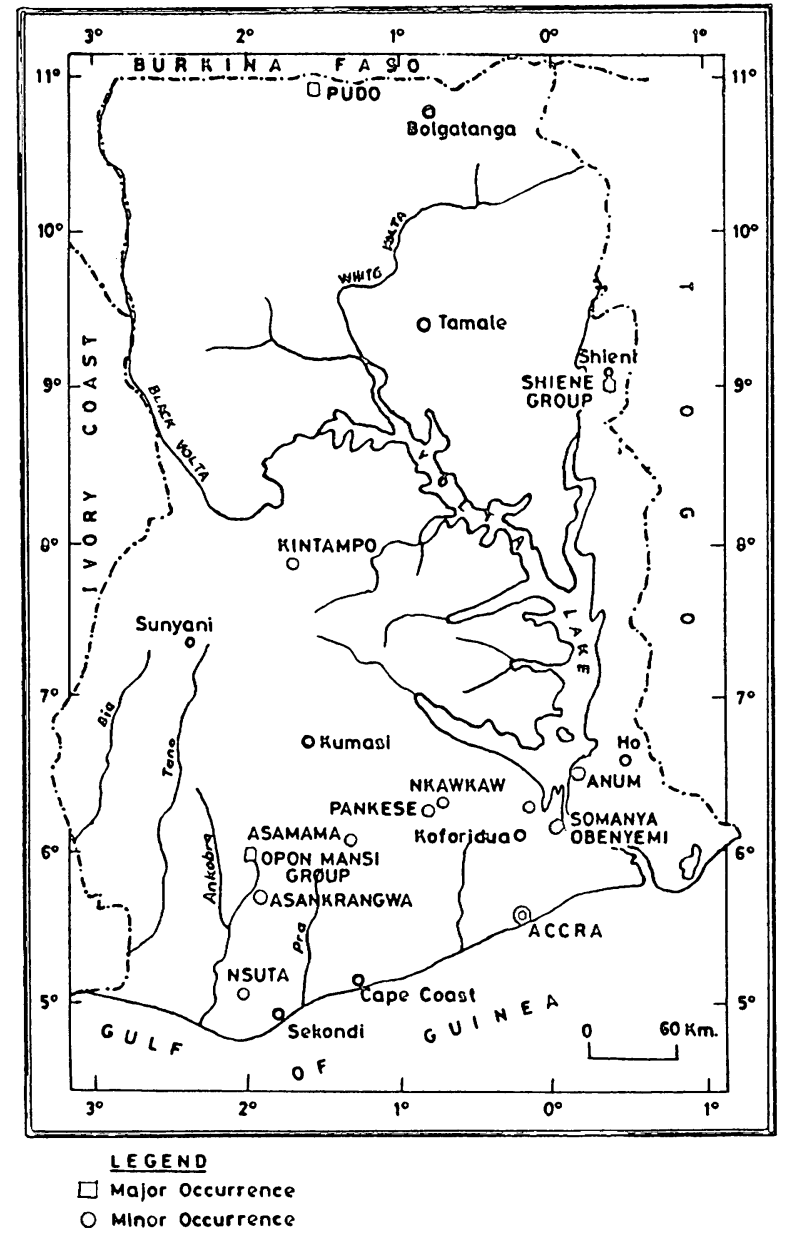

Fig. 3 Iron ore deposits of Ghana.

Table 5. The result of chemical analysis of samples of Opon-Mansi iron ore.

\begin{tabular}{lrr}
\hline Chemical composition & \multicolumn{1}{c}{ Mean $\%$} & \multicolumn{1}{c}{ Range $\%$} \\
\cline { 1 - 3 } $\mathrm{SiO}_{2}$ & 3,32 & $1,24-12,04$ \\
$\mathrm{Al}_{2} \mathrm{O}_{3}$ & 6,43 & $3,05-10,76$ \\
$\mathrm{Fe}_{2} \mathrm{O}_{3}$ & 75,14 & $61,44-80,22$ \\
$\mathrm{FeO}$ & 0,64 & $0,13-0,97$ \\
$\mathrm{CaO}$ & 0,17 & $0,13-0,20$ \\
$\mathrm{MgO}$ & 0,31 & $0,23-0,40$ \\
$\mathrm{Na} 2$ & 0,01 & $10,01-0,07$ \\
$\mathrm{~K}_{2} \mathrm{O}$ & 0,02 & $10,01-0,06$ \\
$\mathrm{TiO}_{2}$ & 1,04 & $0,55-1,98$ \\
$\mathrm{MnO}$ & 0,05 & $0,01-0,29$ \\
$\mathrm{P}_{2} \mathrm{O}_{5}$ & 0,99 & $0,59-1,39$ \\
$\mathrm{H}_{2} \mathrm{O}+105^{\circ} \mathrm{C}$. & 10,43 & $6,97-11,06$ \\
$\mathrm{H}_{2} \mathrm{O}-105^{\circ} \mathrm{C}$. & 1,40 & $0,98-2,14$ \\
\hline
\end{tabular}

the Kubalem ore field which displays great differences in iron and silica contents, but generally averaging $41.6 \% \mathrm{Fe}$ and $29.6 \% \mathrm{SiO}_{2}$, consists of about 600 million tonnes of low grade iron ore. The total estimated reserves of iron ore at the Shieni hills are put at 1270 million tonnes. 
The Opon-Mansi iron ore deposit has about 150 million tonnes of iron ore indicated in an area of 4,050,000 square metres. Out of this, 55 million tonnes have been proven by analysis and the average iron content of this ore was found to be $52.5 \%$. The ore which is mostly hematite and hydrohematite, have small amounts of aluminium and titanium minerals included. The results of chemical analysis of samples of Opon-Mansi ore is shown in Table 5.

The Pudo ore which is largely magnetite generally has more than $75 \% \mathrm{Fe}_{2} \mathrm{O}_{3}$ and between 9 and $11 \% \mathrm{TiO}_{2}$. The total inferred ore reserves at the pudo area is shown as follows:

North of Pudo ... 3,514,300 tonnes

South of Pudo $\quad \ldots \quad 1,001,300$ tonnes

$$
4,515,600 \text { tonnes }
$$

\section{MANGANESE}

The name of Ghana has been associated with high grade manganese since 1916 and it has been difficult for any country to break Ghana's record in the production of this ore during the past 60 years. It has been estimated that over 27 million tonnes of high grade ore have been produced and exported from Ghana. The source of this ore is the Nsuta mines in the Western Region, which has since had its name recorded in geological literature, as the better-grade ore mineral 'Nsutite' is named after it.

The Nsuta-Dagwin manganese deposits are the most important manganese deposits known in Ghana. Exploitation of these deposits began in 1916 and by 1917 shipment of an amount of 20,600 tonnes of ore with a composition of $52.0 \% \mathrm{Mn}, 4.6 \% \mathrm{Fe}, 4.0 \% \mathrm{SiO}_{2}$, and $0.11 \% \mathrm{P}$ had been effected. In February, 1923, the African Manganese Company Limited, was formed to operate the mine. The

Table 6. Details of ore reserves at Nsuta as calculated by the Geological Survey Department in 1964.

\begin{tabular}{|c|c|c|c|c|c|}
\hline \multirow{2}{*}{ Ore type } & \multirow{2}{*}{$\begin{array}{l}\text { Ore } \\
\text { reserves } \\
\text { (tonnes) }\end{array}$} & \multicolumn{4}{|c|}{$\%$ Chemical composition } \\
\hline & & $\mathrm{Mn}$ & $\mathrm{SiO}_{2}$ & $\mathrm{P}$ & $\mathrm{Fe}$ \\
\hline \multicolumn{6}{|l|}{ 1. Oxide ore-high grade } \\
\hline Total & 5038000 & 48,9 & - & - & - \\
\hline $52 \% \mathrm{Mn}$ & 1666800 & 53,6 & - & - & - \\
\hline 48 to $52 \% \mathrm{Mn}$ & 1228400 & 49,9 & - & - & - \\
\hline 40 to $48 \% \mathrm{Mn}$ & 2142800 & 44,7 & - & - & - \\
\hline 2. Oxide ore-low grade & 2013200 & 34,3 & - & - & - \\
\hline \multicolumn{6}{|l|}{ 3. Detrital ore-(Nsuta) } \\
\hline Total & 689700 & 36,3 & - & - & - \\
\hline $40 \% \mathrm{Mn}$ & 239400 & 44,5 & - & - & - \\
\hline 30 to $40 \% \mathrm{Mn}$ & 367000 & 36,0 & - & - & - \\
\hline 20 to $30 \% \mathrm{Mn}$ & 183300 & 27,1 & - & - & - \\
\hline 4. Detrital ore (N.E. of Nsuta) & 1532700 & 26,0 & - & - & 11,0 \\
\hline \multicolumn{6}{|l|}{ 5. Carbonate ore-high grade } \\
\hline $25 \%-\mathrm{Mn} ; 15 \% \mathrm{SiO}_{2}$ & 16943300 & 31,2 & 11,4 & 0,06 & - \\
\hline \multicolumn{6}{|l|}{ 6. Carbonate ore-low grade } \\
\hline 15 to $20 \%-\mathrm{Mn} ; 15 \%-\mathrm{SiO}_{2}$ & 11072100 & 20,3 & 21,4 & 0,07 & - \\
\hline 7. Slime from washing plant & 80000 & 13,1 & - & - & 4,7 \\
\hline
\end{tabular}


rate of production at the time was about 32,500 tonnes monthly and this made the mine the most productive single manganese mine in the world. By the end of 1924, a total of 605,536 tonnes of ore had been exported.

The Nsuta manganese ores are chemically of two main types. These are the oxide and the carbonate types. The chief minerals of the oxide type are pyrolusite and psilomelane. The carbonate rocks are mainly rhodochrosite or dialogite and everywhere they underlie the oxide ore body. The carbonates contain varying amounts of silica and alumina. The average manganese present in eight carbonate rock samples was $34.16 \%$.

It is known that there are about 28 million tonnes of manganese carbonate ore at Nsuta. A break down of the ore reserve figures as calculated by the Geological Survey Department is given in Table 6.

\section{NON-METALLIG MINERALS}

The non-metallic minerals that occur in commercial quantities and are of economic importance in Ghana include Diamonds, Kaolin and Limestone. These minerals are briefly discussed below.

\section{DIAMOND}

The mining of diamonds is one of Ghana's leading industries. This industry started in early 1920 when the Akim Diamondfields Limited started to work deposits at Abomosu. The Consolidated African Selection Trust opened up the very rich deposits at Akwatia in 1923 and 1925, and the West African Diamond Syndicate started operations at Kokotintin in the Eastern Region. At present, diamonds are mined in Ghana by 1. Ghana Consolidated Diamonds (GCD) Limited, 2. Cayco (Ghana) Limited, 3. Amalgamated Mining Company, 4. Dunkwa Goldfields Limited of the State Gold Mining Corporation and 5. Private diamond winners.

Ghana Consolidated Diamonds (GCD) Limited is the chief producer of diamonds in Ghana accounting for over $90 \%$ of all the diamonds produced in the country since 1923 to present. They have a concession area of up to $152.2 \mathrm{sq} \mathrm{km}$ and has produced not less than 70 million carats of diamonds from 29 million cubic metres of gravels, treated at a grade of 2.44 carats per cubic metre. The other companies have concession areas as follows:
Cayco (Ghana) Limited
$5.74 \mathrm{sq} \mathrm{km}$
Diamond Winners and Amalgamated Company Ltd. $4.0 \mathrm{sq} \mathrm{km}$
Ex-Akim Concessions
$48.1 \mathrm{sq} \mathrm{km}$
Ghana Mineral Trading Corporation
$25.8 \mathrm{sq} \mathrm{km}$

All together these companies in addition to private winners produced a total of 6,616,039 carats of diamond between the period $1977 / 78$ to $1981 / 82$.

The principal diamondiferous areas as shown in Fig. 4 include, the Birim diamonfield, the Bonsa diamondfield, the Dunkwa/Jimi field and the Nyafomang field. The diamonds in these fields are normally associated with such heavy minerals as staurolite, ilmenite, rutile, and tourmaline. The main concentrations of the diamonds occur in the shallow tributary valleys and associated interfluvial deposits in the Akwatia area, but many other tributaries and terraces of the Birim River also contain workable deposits. It is estimated that the Birim flats still hold more than 50 million carats of diamonds. Proved blocks within the existing Akwatia mining area has presently a total ore reserves of $2,590,000$ cubic metres, estimated to be containing about 3,740,000 carats of diamonds. 


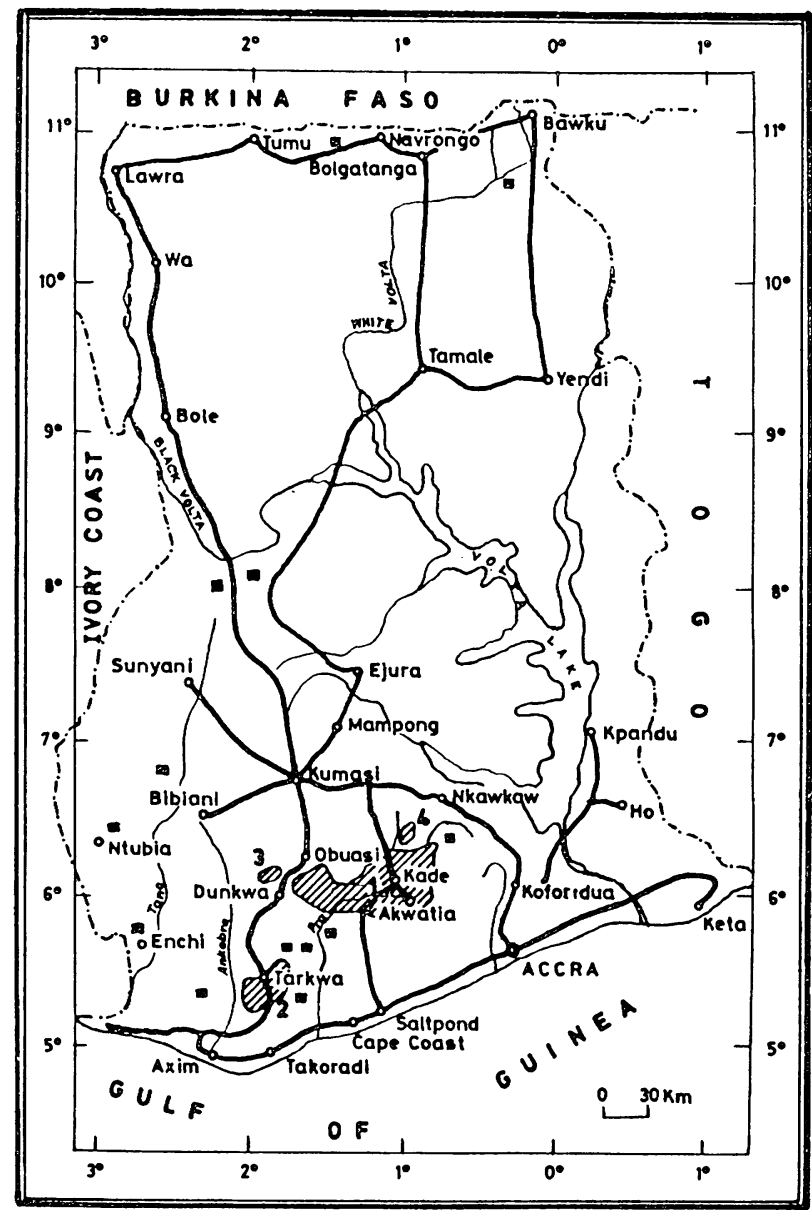

\section{LEGEND}

- Isolated diamond

1 Birim diamondtield

2 Bonsa diamondfield

3 Dunkwa/Jimi diamondfleld

4 Nyafomang diamondfield

Fig. 4 Locations of diamondiferous areas in Ghana.

The middle Birim ore reserves position presently is $7,360,700$ cubic metres of full gravel horizon capable of producing about $9,446,000$ carats of diamonds.

\section{KAOLIN}

The best known kaolin deposits in Ghana are those found at the Abandze-Saltpond by-pass in the Central Region and at Kibi in the Eastern Region. The Abandze-Saltpond by-pass deposits are known to be closely associated with some 30 pegmatite bodies, six of which are thought to be of commercial grade. It is estimated that these six deposits contain over 1,020,000 tonnes of pegmatite material suitable for the extraction of kaolin. The mineralogy of the deposit using X-ray diffraction methods indicated $97 \%$ kaolinite, $2 \%$ quartz and $1 \%$ muscovite, while chemical analysis gave the following results.
$\mathrm{SiO}_{2}$
$\mathrm{Al}_{2} \mathrm{O}_{3}$
$35.5 \%$ 
Table 7. Physical properties of 2 samples from Kibi kaolin deposit.

\begin{tabular}{|c|c|c|c|}
\hline & \multicolumn{2}{|r|}{ Sample (A) } & \multirow{2}{*}{$\frac{\text { Sample (B) }}{\%}$} \\
\hline & & $\%$ & \\
\hline Shrinkage by drying & ...... & 2,70 & 2,40 \\
\hline Shrinkage by firing at $1250^{\circ} \mathrm{C}$ & ...... & 9,05 & 9,20 \\
\hline Total shrinkage & ...... & 11,75 & 11,60 \\
\hline Loss by drying & ...... & 32,70 & 31,00 \\
\hline Loss by firing at $1250^{\circ} \mathrm{C}$ & ....... & 13,70 & 13,00 \\
\hline Total loss & ...... & 46,40 & 44,50 \\
\hline Initial compression strength $\left(\mathrm{kg} / \mathrm{cm}^{2}\right)$ & ...... & 0,14 & - \\
\hline Soakability (Porosity) & ...... & - & 5,80 \\
\hline Colour before firing & ...... & - & White \\
\hline Colour after firing & ...... & Pure white & Creamy-white \\
\hline Hardness at green state & $\ldots \ldots$ & - & $\begin{array}{l}\text { Easily scratched } \\
\text { by finger nail }\end{array}$ \\
\hline Plasticity & $\ldots \ldots$ & - & Low \\
\hline
\end{tabular}

$\begin{array}{lr}\mathrm{Fe}_{2} \mathrm{O}_{3} & 2.4 \% \\ \mathrm{H}_{2} \mathrm{O} & 16.8 \%\end{array}$

At present, the Saltpond Ceramics Limited is utilizing the kaolin reserves in the Saltpond area for the manufacture of crockery, toilet bowls, hand washing basins and refractories.

The Kibi kaolin deposits are usually grey or white in colour and very pure. Kaolinite, quartz and mica are the main minerals present in the kaolin with kaolinite as the principal mineral. It constitutes about 60 to 100 per cent of the rock with an average of about $60 \%$. These deposits are the largest known kaolin deposits in Ghana. About 1,520,000 cubic metres of kaolin have been estimated from the three swamps which cover the deposits. On the whole however, calculations have revealed that there is a total of about 3,234,043 metric tonnes of kaolin at Kibi. Table 7 above shows a summary of the physical properties of Kibi kaolin.

\section{LIMESTONE}

Although many limestone deposits occur in Ghana, only five deposits may be considered for economic exploitation. These are the Nauli, Bongo-Da, Oterkpolu, Fo River, and the Daboya deposits.

The limestone reserves at Nauli was evaluated in 1977 for its utilization as a flux in a proposed intergrated iron and steel complex. The total reserves at the time stood at 12 million tonnes within an area of $1,100,000$ square metres with an average of more than $50 \% \mathrm{CaO}$. However, recent borehole tests have established reserves of 400 million tonnes and a potential of about 1000 million tonnes within the entire Tano Basin. Despite difficulties associated with the mining of these large deposits, 23 million tonnes of limestone outcrops known to be occurring at the surface could be mined by open cast methods.

It is estimated that, the Bongo- $\mathrm{Da}$ area have at least 15 million tonnes of very good quality limestone and some 20 to 30 million tonnes of dolomite. Generally, the limestone in this area averages $40-49 \% \mathrm{CaO}, 1.2-4.2 \% \mathrm{MgO}, 9.0-9.3 \% \mathrm{SiO}_{2}$ and $1.7-3.9 \% \mathrm{Al}_{2} \mathrm{O}_{3}$. Investigations also revealed that the deposits contain 6.62 million tonnes of low magnesium limestone which could be mined from four quarry sites in the area.

The Buipe limestone deposits represents the largest occurrence of magnesian limestone rocks in 


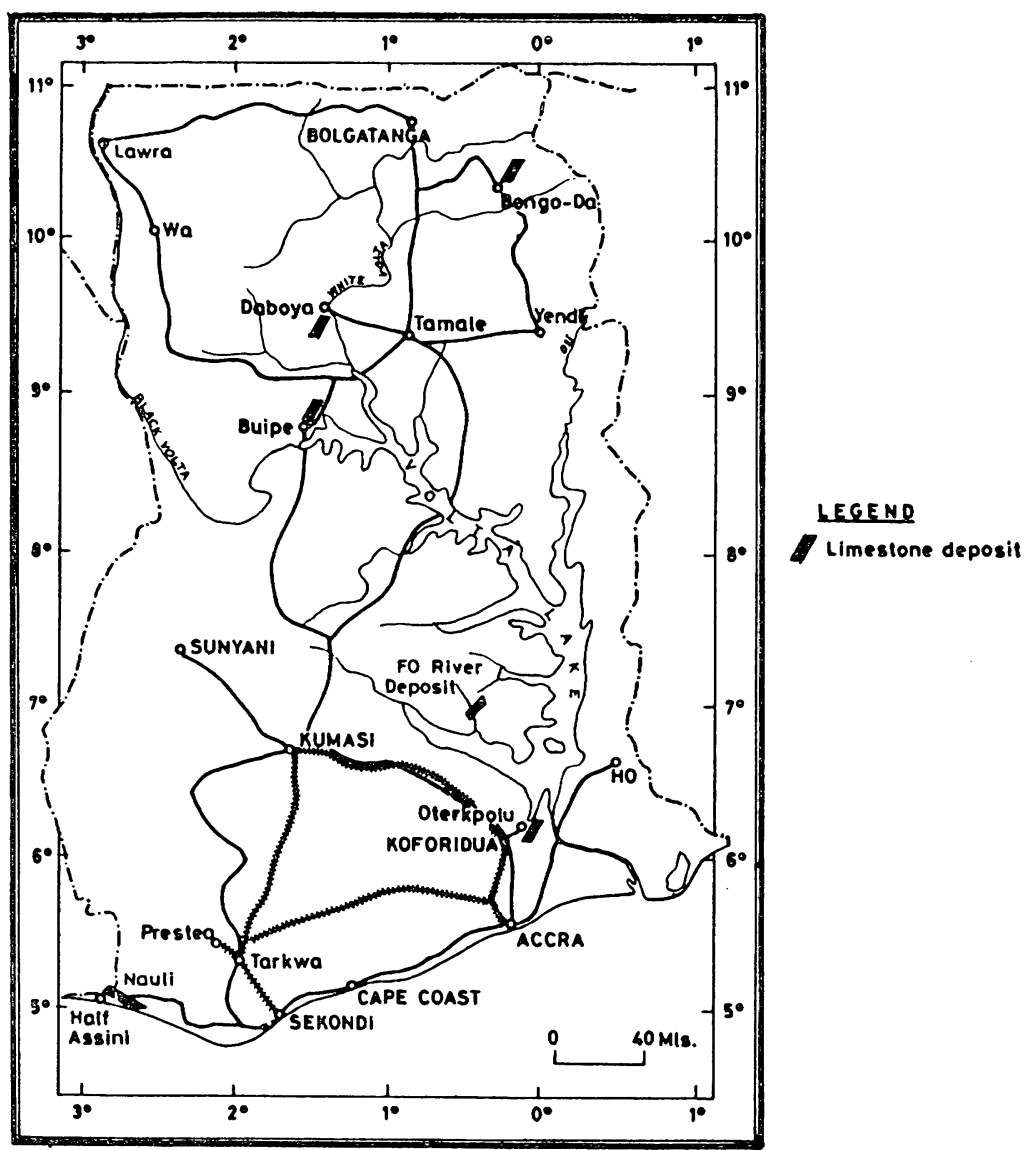

Fig. 5 Locations of the most important limestone deposits of Ghana.

Northern Ghana. The chemical composition varies considerably, however, the limestone generally contains about $48 \% \mathrm{CaO}$ while the dolomite have about $30 \% \mathrm{CaO}$. The total reserves of the limestone and mudstone are estimated at 6.03 million metric tonnes while those of the dolomite are about 138 million metric tonnes. The reserves of dolomitic limestone and dolomite in the lower horizon are estimated at 400 million tonnes.

A preliminary investigation into the Oterkpolu limestone deposits by the Geological Survey Department have indicated reserves of limestone for open cast mining in two blocks, i.e. near Oterkpolu and near Niensi. At Oterkpolu, the available quantity of limestone has been estimated in the neighbourhood of 3 million tonnes, and 0.7 million tonnes at Niensi. The approximate amount of limestone found through investigations conducted by the Ghana Cement Works was 8 to 1,0 million tonnes averaging $60 \%$ calcium carbonate. Other limestone deposits include the Fo River deposit containing about 15 million tonnes of limestone and the Daboya deposits containing 162,000 tonnes with over 500,000 tonnes of dolomitic limestone. Fig. 5 shows the locations of the most important limestone deposits of Ghana.

Most of the country's limestone deposits are suitable for the manufacture of Portland cement, clinker, refractory materials and white lime.

\section{PETROLEUM}

Even though nearly half of Ghana's total area, i.e. about. 135,000 square kilometres is covered 
Table 8. Quantity of oil produced from Saltpond Field by Agri-Petco of Ghana Incorporated

\begin{tabular}{lcc}
\hline & Period & Quantity (in barrels) \\
1st Oct. & - 31st Dec., $1978-$ & 295988 \\
1st Jan. - 31st Dec., $1979-$ & 655781 \\
1st Jan. - 31st Dec., $1980-$ & 664254 \\
1st Jan. - 31st Dec., 1981 & - & 599797 \\
1st Jan. - 31st Dec., $1982-$ & 434750 \\
1st Jan. - 31st Dec., $1983-$ & 498634 \\
& Total & 3149204 \\
\hline
\end{tabular}

by sedimentary rocks, there is still not much certainty of finding oil in commercial quantities in the country. The sedimentary rocks found mainly in four different parts of the country, had attracted the attention of oil companies and for the past several years, oil prospecting had been concentrated in these areas. The areas include the Tano Basin, the Keta Basin, the Voltaian Basin and the continental shelf. So far from the results of the prospecting of the various companies, the continental shelf is the only place which has produced small quantities of petroleum. In June 1970, Signal Oil Company discovered oil in a well about $14.4 \mathrm{~km}$ south of Saltpond. Initial tests carried out by the company showed that the well could produce a total of 3,600 barrels of oil a day. The quality of oil was good with the sulphur content being $0.5 \%$. The company's geologists estimated the total reserves in this area at about 7.5 million barrels.

In 1977, Agri-Petco International, a U.S.A. company, drilled three offshore wells off the coast of Saltpond and the results of the drilling activities were encouraging. The company estimated that each of the three wells was capable of producing about 1000 barrels of oil per day. By 1978, six wells had been drilled and the company decided to develop this field. The initial daily production rate was to be 5000 to 6000 barrels of oil a day. Table 8 shows the quantity of oil which has been produced since 1st October, 1978, when Agri-Petco started producing oil from the Saltpond field.

It could be observed from the table that, so far, this company has produced 3,149,204 barrels of oil between the period of 1st October, 1978 and 31st December, 1983. Difficulties have been experienced in production from this field because the reservoir consists of seven thin pay sand with several different oil/water and gas/oil interfaces. The reservoir pressure has fallen below the bubble point and due to this production has declined to less than 2000 barrels of oil per day. Infact, by the end of February, 1982, production had declined to about 1350 barrels of oil per day.

\section{REFERENCE}

Kesse, G. O., 1985. The Mineral and Rock Resources of Ghana. 